\title{
Pemberdayaan UMKM Melalui Digitalisasi Keuangan Menggunakan Aplikasi Catatan Keuangan di Pasar Kranggan Wilayah Kecamatan Jati Sampurna Kota Bekasi Jawa Barat
}

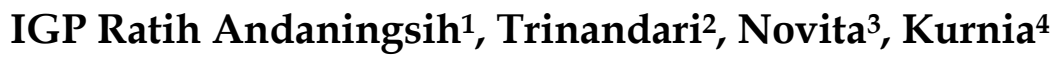 \\ ${ }^{1}$ Fakultas Ekonomi, University of Borobudur Jakarta \\ e-mail: ratihiai@ymail.com \\ 2Institute Perbanas Jakarta \\ e-mail: trinandari@yahoo.com \\ 3 University of Trilogi Jakarta \\ e-mail: novita_1210@universitas-trilogi.ac.id \\ 4STIE MMC Jakarta \\ e-mail: kurnia@yahoo.com
}

\begin{abstract}
Abstrak
Penulis ingin mengetahui para pelaku UMKM dalam memahami digitalisasi keuangan dalam menggunakan aplikasi catatan keuangan untuk kegiatan usaha UMKM. Dalam hal ini penelitian melakukan penelitian ini bertujuan untuk mengetahui lebih mendalam mengenai digitalisasi keuangan dalam menggunakan aplikasi catatan keuangan yang dapat meningkatkan produktifitas kinerja dan usaha. Metode penelitian ini menggunakan deskriptif kualitatif melalui hasil wawancara secara jarak jauh dan jarak dekat yang diwakili sebanyak 25 orang. Manfaat penelitian adalah supaya pelaku UMKM dapat lebih memahami pencatatan transaksi keuangan dalam meningkatkan tata kelola keuangan usaha UMKM. Batasan penelitian ini dibatasai hanya pada pemberdayaan UMKM melalui digitalisasi keuangan dengan menggunakan aplikasi catatan keuangan pada media handphone atau Ipad untuk pelaku usaha UMKM. Kontribusi penelitian ini adalah meningkatkan layanan digitalisasi keuangan dalam menggunakan aplikasi catatan keuangan pada sektor perdagangan dan sektor industri kreatif secara tangguh dan produktif. Hasil penelitian dan pengabdian kepada masyarakat ini adalah mencakup pemberdayaan UMKM melalui digitalisasi keuangan menggunakan aplikasi catatan keuangan dan optimalisasi jaringan layanan bisnis UMKM secara digitalisasi keuangan dan program pemberdayaan UMKM melalui Aplikasi Catatan Keuangan.
\end{abstract}

Kata Kunci: Pemberdayaan UMKM, Digitalisasi Keuangan, Aplikasi catatan keuangan,Ekonomi

\section{Abstract}

The author wants to know MSME actors in understanding financial digitization in using financial record applications for MSME business. The research method uses qualitative descriptive through the results of long distance and short distance interviews represented by 25 
respondens. Benefit of the research is that MSME actors can better understand the recording of financial transactions in improving MSME business financial governance. The improving of financial digitization services in using financial record applications in the trade sector and the creative industry sector in a strong and productive. Results of this research and community service include empowering MSMEs through financial records applications and optimizing the MSME business service network through financial digitization and the MSME Empowerement program through the application of financial records.

\section{Key Words: MSME Empowerment, Financial digitalization, Financial record application, Economics}

\section{Pendahuluan}

Dijaman serba digital ini, pertumbuhan UMKM sebagai sektor penting yang menopang pertumbuhan ekonomi nasional yang dinilai belum maksimal, diharapkan dilakukan berbagai upaya oleh pemerintah dan pemangku kepentingan lainnya. Upaya untuk mendorong para pelaku UMKM ini untuk bisa go online dengan memanfaatkan internet, sarana handphone termasuk penggunaan aplikasi digital lainnya seperti Ipad untuk mengembangkan bisnis usaha. Sangat dibutuhkan dukungan dari banyak pihak meyakini produk UMKM lokal bisa berjaya di pasar global. Jumlah UMKM yang sudah go online saat ini masih relatif sedikit dibandingkan dengan jumlah keseluruhan UMKM. Berdasarkan data terbaru dari Kementerian Komunikasi dan Informatika Dari total sekitar 60 Juta UMKM yang ada di Indonesia, baru sekitar 9,4 juta UMKM yang sudah go online. Kementerian Koperasi dan UKM serta Kementerian Kominfo, telah menargetkan untuk mengonlinekan 8 juta UMKM sampai dengan tahun 2021 dan selanjutnya ini. Dengan banyaknya peluang yang terbuka lebar untuk kemajuan UMKM di Indonesia. Seberapa mampukah mereka dapat menjalankan dan mengembangkan usaha secara lebih produktif dan kreatif dengan berbagai inovasi dan terobosan di tengah persaingan yang semakin ketat dan sangat kompetitif ini sangatlah dibutuhkan manajemen keuangan yang baik dan tata kelola keuangan usaha yang baik yang dapat mengawasi usaha untuk pengeluaran dan penerimaan uang atas hasil usahanya supaya tidak menderita kerugian secara material.

Di Play store banyak sekali aplikasi yang dapat membantu lebih dari 250.000 UMKM untuk dapat melakukan pengelolanan dan pemantauan keuangan usaha secara mudah dan praktis melalui aplikasi catatan keuangan dimanapun dan kapanpun. Kecamatan Jati Sampurna adalah sebuah Kecamata yang berada di Kota Bekasi Provinsi Jawa Barat dimana wilayah ini sangat ramai dan potensi perluasan lahan UMKM terutama sektor Home Industri dan ekonomi kreatif UMKM Kontr ibusi nilai ekspor pertanian dan perdagangan mencapai US\$ 0,4 miliar atau 3,0\% dari total ekspor Indonesia. Kegiatan sektor perdagangan kelontongan merupakan salah satu pesat menciptakan akselerasi percepatan perekonomian khususnya di Wilayah Pasar Kranggan untuk Para Pedagang. 
Sektor perdsagangan dan industri kreatif menjadi salah satu sektor unggulan di masa Pandemi Covid 19 untuk menciptakan lapangan pekerjaan yang produktif. Sektor perdagangan kelontongan yang berfokus pada peningkatan kualitas dan pelayanan kepada masyarakat khususnya kebutuhan Sembilan barang/bahan pokok (SEMBAKO) masyarakat yang dilakukan oleh pengusaha UMKM yang bergerak dalam sektor perdagangan dalam perbaikan, maupun dari segi pertumbuhan ekonomi nasional yang diukur melalui Produk Domestik Bruto dan di wilayah Pasar Kranggan Kecamatan Jati Sampurna Kota Bekasi Jawa Barat, khususnya yang bergerak di sektor perdagangan dan industry kreatif.

Hampir di seluruh sektor usaha khususnya Pengusaha agro bisnis pertanian yang melakukan pengusaha. Tentunya dengan memanfaatkan digital teknologi, Pengusaha UMKM bidang agrobisnis pertanian sangat memiliki peluang untuk menjadi pilar ekonomi kerakyatan khususnya para pengusaha yang bergerak di sektor perdagangan dan industri kreatif dan craft. Pemerintah mulai melirik industry kreatif sebagai alternatif roda penggerak perekonomian nasional yang akan terus berputar pada posrosnya untuk meningkatkan pertumbuhan ekonomi nasional. Evaluasi penilaian hasil Kinerja para pelaku pengusaha perdagangan khususnya Sembako dilakukan melalui program pemberdayaan terpadu. Adanya penyederhanaan periijinan dalam penerapan sistem perijinan usaha berbasis risiko menjadi keunggulan perdagangan dan industry kreatif, dan agro bisnis. Sektor agrobisnis pertanian dan perikanan mengalami perubahan regulasi iharapkan memberikan hawa segar khususnya sektor agrobisnis bidang pertanian dan diharapkan dapat meningkatkan kesejahteraan masyarakat Indonesia.

Pengenalan tentang Mobile Application yang didefinisikan sebagai program komputer yang dirancang khusus pada peranti yang bergerak seperti ponsel, tablet, smartphone atau smartwatch (Wao, liao, yang, 2013). Perbedaan mobile application dengan aplikasi desktop terletak pada mobilitas dari kedua aplikasi dalam mengakses aplikasi catatan keuangan terkesan lebih praktis karena dapat diakses melalui ponsel, tablet, yang notabene ringkas dalam kondisi mobilitas yang tinggi (Berpindahpindah). Menurut Pressman dan Bruce (2014), mobile application adalah aplikasi yang telah dirancang khusus untuk platform mobile yang memiliki sistem pengoperasian tertentu diantaranya IOS yang dikembangkan oleh Apple Inc,Android yang dikembangkan oleh Google, serta Windows Mobile yang dikembangkan oleh Microsoft.

Sektor industri kreatif,perdagangan, agro bisnis dapat meningkatkan dan bertumbuh secara produktif melalui peningkatan hasil produktifitas pertanian secara produktif dengan memperhatikan kebutuhan di masyarakat dan kemampuan daya beli masyarakat .Dukungan dan mo tivasi kepada masyarakat di wilayah Kecamatan Jati Sampurna dan sekitarnya diharapkan mampu mendongkrak penghasilan warga yang memiliki penghasilan rendah ungtuk bergerak maju ke agrobisnis sektor pertanian yang produktif yang mampu menjadi solusi untuk menghadapi tantangan ekonomi global yang diprediksi akan menggeser system ekonomi yang telah berjalan (Syarif dan Azizah, 2015) (Daulay ,2018). 
Tabel 1 Konten dari pelaksanaan kegiatan Pengabdian Kepada Masyarakat

\begin{tabular}{|c|l|}
\hline No & \multicolumn{1}{|c|}{ UMKM Di Wilayah Kecamatan Jati Sampurna Kota Bekasi Jawa Barat } \\
\hline 1. & $\begin{array}{l}\text { Pengabdian kepada pasyarakat melalui: Sosialisasi penggunaan aplikasi catatan keuangan } \\
\text { untuk mencatat transaksi harian UMKM kepada pedagang Sembako dan industry } \\
\text { kerajinan dan Agrobisnis di Pasar Kranggan }\end{array}$ \\
\hline 2. & $\begin{array}{l}\text { Pengabdian kepada Masyarakat: Memberikan cara penggunaan Aplikasi catatan } \\
\text { keuangan kepada/ bagi pelaku usaha UMKM khususnya para pelaku usaha Agrobisnis } \\
\text { pertanian untuk terus meningkatkan produksinya secara integrasi dan jaringan dan } \\
\text { penggunaan teknologi digital dan bidang sektor perdagangan khususnya di daerah Pasar } \\
\text { Kranggan }\end{array}$ \\
\hline 3. & $\begin{array}{l}\text { Pengabdian kepada Masyarakat melalui dukungan serta memberikan masukan untuk } \\
\text { meningkatkan hasil usahanya dengan digitalisasi dengan menggunakan aplikasi digital } \\
\text { dri catatan keuangan lewat HandPhone atau Ipad di wilayah Kecamatan Jati Sampurna } \\
\text { secara daring dan secara langsung ke lapangan seprti mendatangi pelaku UMKM di Pasar } \\
\text { Kranggan }\end{array}$ \\
\hline 4 & $\begin{array}{l}\text { Pengabdian Kepada Masyarakat mengenai pentingnya pencatatan trasaksi harian } \\
\text { melalui aplikasi digitalisasi untuk mempermudah monitoring keuangan khususnya uang } \\
\text { masuk dan uang keluar (Penerimaan dan pengeluaran) atas aktifitas kegiatan sehari } \\
\text { harinya untuk meningkatkan kinerja usaha UMKM di Pasar Kanggan }\end{array}$ \\
\hline
\end{tabular}

Masyarakat pelaku usaha Agro Bisnis wajib melakukan Protokol Kesehatan penuh setiap melaksanakan aktivitas dan kegiatan di luar rumah, kita diwajibkan untuk mengikuti petunjuk untuk disiplin mengikuti Protokol Kesehatan untuk menjaga Kesehatan dan kebugaran tubuh untuk tetap sehat dan prima untuk menjaga imunitas tubuh kita supaya tetap sehat dan kuat.

Melakukan kegiatan pengabdian kepada masyarakat dengan menggunakan aplikasi catatan keuangan, lewat sarana handphone atau Ipad secara individual dengan mendatangai secara langsung kepada pelaku UMKM secara berkesinambungan di periode mendatang.

Tabel 2. Fitur pada Aplikasi Catatan Keuangan pada Media Aplikasi Handphone atau Ipad

\begin{tabular}{|c|c|l|}
\hline Fitur I & Penerimaan & $\begin{array}{l}\text { Menggambarkan transaksi transaksi untuk mencatat penerimaan } \\
\text { uang kas harian kegiatan UMKM }\end{array}$ \\
\hline Fitur II & Pengeluaran & $\begin{array}{l}\text { Menggambarkan transaksi untuk mencatat pengeluaran uang kas } \\
\text { harian kegiatan UMKM }\end{array}$ \\
\hline
\end{tabular}

Sumber data: Data diolah dari fitur aplikasi Catatan Keuangan di Handphone dan Ipad (Smart Phone dan Ipad tahun 2021)

Tujuan dan Manfaat dari Kegiatan Pengabdian Kepada Masyarakat ini adalah:

1. Untuk lebih meningkatkan pemahaman pelaku usaha UMKM dalam melakukan pencatatan transaksi keuangannya secara digital melalui media sederhana seperti Handphone, smartphone, Ipad dan fasilitas lain yang mendukung melalui Aplikasi catatan Keuangan.

2. Lebih meningkatkan kesadaran pelaku UMKM untuk mengetahui saldo untung atau rugi setiap saat 
3. Untuk lebih mudah dan efisien dalam melakukan pengawasan transaksi keuangan sehari harinya dan monitoring kegiatan melakukan transaksi keuangan harian dan aktifitas penjualan setiap hari

4. Meningkatkan mutu dan kualitas tatakelola keuangan usaha UMKM secara mandiri dan profesional

\section{Metode}

Kegiatan pengabdian kepada masyarakat ini sekaligus untuk penelitian yaitu melakukan teknik wawancara atas data yang terkumpul melalui observasi melaui wawancara secara langsung terhadap 25 Informan pelaku UMKM di Daerah sekitar Pasar Kranggan. Tujuan penelitian ini adalah untuk mengetahui seberapa jauh masyarakat di Wilayah secara langsung tempat kejadian transaksi (TKT) di Wilayah Kecamatan Jati Sampurna khususnaya di daerah Pasar Kranggan untuk mengetahui kondisi pelaku UMKM dan sesuai mitra pemilik UMKM tersebut untuk memahami betapa pentingnya pencatatatan transaksi keuangan atas penjualan UMKM tersebut. Menurut (Sugiono, 2013) analisis data adalah mengembangkan teori yang telah di bangun dari data yang sudah didapatkan di lapangan. Dokumentasi berupa foto-foto berguna untuk mengetahui hasil fakta dari penelitian.

Informan dalam penelitian ini adalah para pelaku UMKM yang terdiri dari Pelaku UMKM bidang pedagang Sembako, Pengusaha sayur dan buah buahan Agrobisnis pertanian, dan Pedagang minuman dan makanan (Fast Food) siap saji Di Wilayah Kecamatan Jati Sampurna di Kota Bekasi Jawa Barat yang diwakili oleh 25 orang informan dan responden untuk penelitian dan Pengabdian Kepada Masyarakat yang dilakukan melalui tahapan Identifikasi masalah, pengumpulan data berdasarkan hasil wawancara, mengklasifikasikan data, dan kemudian menganalisis data berdasarkan hasil wawancara dan kemudian mendeskripsikan data (Sugiyono, 2012). Dalam menggunakan data deskriptif kualitatif yaitu di daerah Pasar Kranggan secara langsung sesuai data yang terkumpul baik secara langsung maupun WA Japri mengenai permasalahan yang terjadi di lapangan terutama terkait pencatatan transaksi keuangan kegitan UMKM.

\section{Hasil dan Pembahasan}

Kecamatan Jati Sampurna sebagai salah satu Kecamatan yang berada di Wilayah Kota Bekasi dan tepatnya dekat sekali lokasinya dekat Pasar Kranggan, Profinsi Jawa Barat yang memiliki yang memiliki potensi peningkatan produksi bidang usaha agrobisnis pertanian, perdagangan dan sektor industri kreatif. Daerah ini merupakan daerah alami dan ramah lingkungan tanaman dan tumbuhan dan penuh penghijauan dan salah satu daerah yang memiliki kelebihan tersendiri. Penelitian kami lakukan pada wilayah Kecamatan Jati Sampurna yaitu sebanyak 25 orang pelaku pengusaha agrobisnis bidang pertanian yang bergelut bidang pertanian industri, agro bisnis, makanan dan minuman, peternakan dan sektor agro bisnis industri lainnya berdasarkan usi sebagai informan kunci. 


\section{Cara Mengaktifkan Aplikasi Catatan Keuangan untuk Mitra UMKM dan} Pelaku UMKM

a. Program pertama yang kami lakukan yaitu pembuatan aplikasi digital untuk catatan keuangan lewat download di playstore Hand Phone sebagai perangkat kerja sarana kerja UMKM yang sederhana dan Ipad yang diperuntukkan bagi pemilik Mitra UMKM dan UMKM kelas Menengah.

b. Memastikan Aplikasi catatan keuangan sudah terpasang pada selular handphone /Ipad masing masing pelaku UMKm khususnya did aerah Pasar Kranggan

c. Mendapatkan kemudahan akses untuk mencatat transaksi keuangan ke dalam aplikasi catatan keuangan

d. Mendapatkan pendapingan cara mengaplikasikan dan memasukkan transaksi penerimaan dan pengelauran pada unit mitra UMKM khususnya di daerah Pasar Kranggan

e. Mendorong para pelaku UMKM untuk disiplin dalam hal mencatat transaksi hariannya ke dalam aplikasi catatan keuangans etiap saat terjadinya transaksi dengan tujuan monitoring saldo kas harian atas kegiatan UMKM mitra Tersebutsetiap ahrinya. Dengan menjelaskan manfaat dari penggunaan aplikasi catatan keuangan sebagai mediator dalam transaksi bisnis usaha UMKM khususnya di daerah Pasar Kranggan Kecamatan Jati Sampurna diharapkan Pelaku UMKM mitra UMKM tersebut dapat memonitoring laba/rugi usahanya setiap harinya dna meningkatkan produktifitas kinerjanya setiap hari.

\section{Sosialisasi Digital Keuangan lewat Aplikasi Catatan Keuangan}

Aktifitas pelaku UMKM di daerah PasarKranggan sangat banyak sekali khususnya bidang perdagangan, khususnya para pedagang sayur, buah dan pedagang kelontong. Pada Hari Minggu Tanggal 07 November Tahun 2021 Pukul 10.00-11.00 Wib kami melaksanakan Sosialisasi mengenai penggunaan aplikasi catatan keuangan secara langsung dan secara mandiri kepada para pelaku bisnis UMKM, contohnya pedagang beras di Pasar Kranggan.

Pada kegiatan Sosialisasi tersebut kami menjelaskan bagaimana menggunakan aplikasi catatan keuangan dengan baik dan benar untuk memasukkan semua transaksi harian atas transaksi pembelian dan penjualan beras di masyarakat. Google gratis melalui Aplikasi Play Store merupakan alat gratis digital yang mudah diakses oleh pebisnis UMKM dan itra UMKM termasuk penelusuran Maps (Dwiarta dan Choiria,2017). Evaluasi yang kami lakukan kepada mitra dan pebisnis UMKM adalah memberikan kuesioner seputar penggunaan aplikasi catatan keuangan. Hasil kuesioner yang telah dilakukan dan sebelum dan sesudah sosialisasi digital financial di Pasar Kranggan Tersebut dapat dilihat berdasarkan nilai yang diperolehh dari masing masinag responden dan informan (mitra). 
Tabel 2 Data Informan Kunci Pelaku usaha UMKM (MITRA) di Wilayah Kecamatan Jati Sampurna Kota Bekasi

\begin{tabular}{|c|l|c|}
\hline No & \multicolumn{1}{|c|}{ Nama UMKM (Mitra) Pelaku UMKM } & $\begin{array}{c}\text { Jumlah } \\
\text { UMKM }\end{array}$ \\
\hline 1. & $\begin{array}{l}\text { Pengusaha UMKM Kelompok Pedagang Kelontong penyedia } \\
\text { bahan kebutuhan pokok masyarakat yang bergerak di sektor } \\
\text { perdagangan } \\
\text { Terdiri dari: Pedagang beras dan pedagang Sembilan kebutuhan } \\
\text { pokok (SEMBAKO) }\end{array}$ & 10 \\
\hline 2. & $\begin{array}{l}\text { Pengusaha UMKM (mitra) yang bergerak bidang perdagangan } \\
\text { sayur dan buah buahan }\end{array}$ & 9 \\
\hline 3. & $\begin{array}{l}\text { Pengusaha UMKM (Mitra) yang bergerak dalam bidang hasil } \\
\text { produk pertanian olahan, makanan dan minuman siap saji }\end{array}$ & 6 \\
\hline \multicolumn{1}{|c}{ Jumlah Responden/Informan } & 25 \\
\hline
\end{tabular}

Sumber data: Data diolah peneliti (November 2021)

Tabel 3. Karakteristik Informan berdasarkan Umur

\begin{tabular}{|c|l|c|c|}
\hline No & Usia/Umur & Jumlah Informan & Persentase \\
\hline 1. & Kurang < dari 20 tahun & 6 & $24 \%$ \\
\hline 2. & 21 thn-30 thn & 4 & $16 \%$ \\
\hline 3. & 31 thn-40 thn & 5 & $20 \%$ \\
\hline 4. & Lebih>40 tahun & 10 & $40 \%$ \\
\hline \multicolumn{2}{|c|}{ Jumlah } & 25 & 100 \\
\hline
\end{tabular}

Sumber: Data diolah oleh peneliti (November 2021)

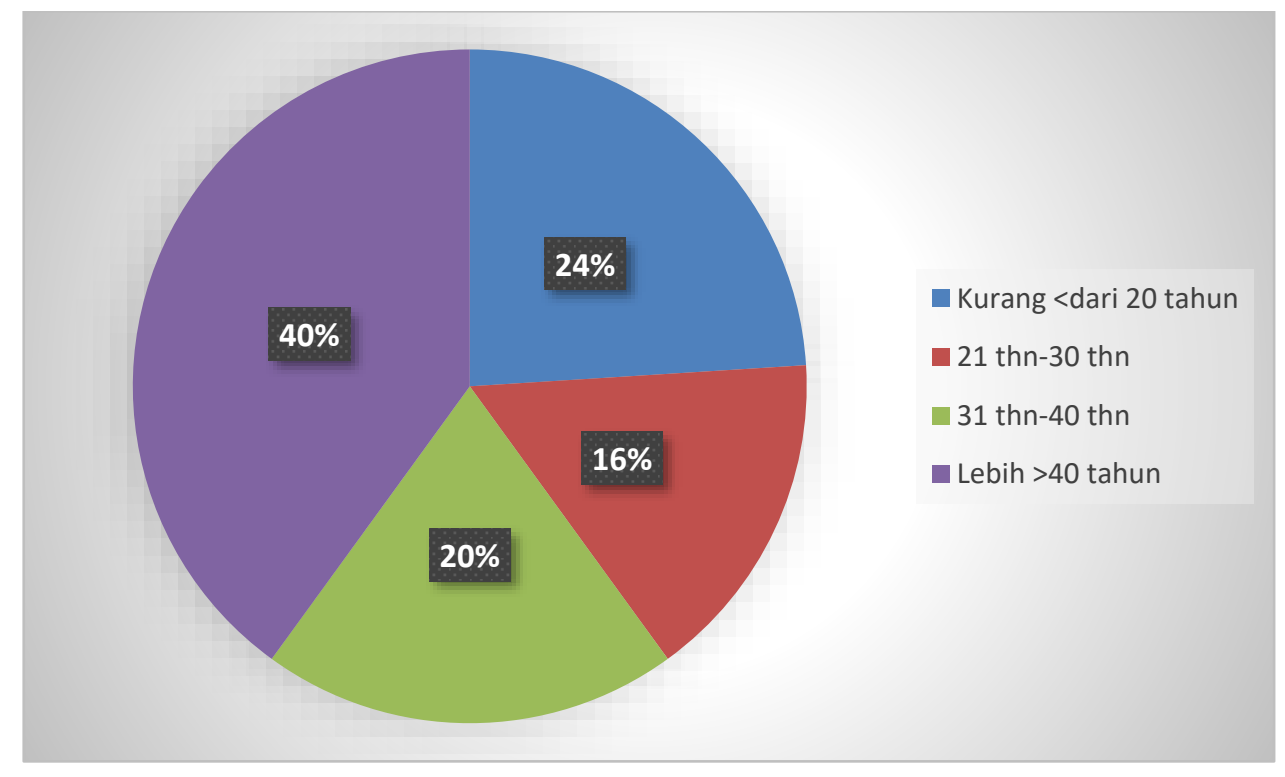

Gambar 1. Karakteristik Informan berdasarkan Umur

Hasil Pengabdian Kepada Masyarakat dan penelitian yang didapat setelah melakukan wawancara dan survey terlihat dalam diagram lingkaran yang menunjukkan tingkat persentase sesuai dengan karakteristik usia para pelaku 
pengusaha agrobisnis pertanian di Wilayah Pasar Kranggan dan sekitarnya Kecamatan Jati Sampurna Kota Bekasi Jawa Barat. Kegiatan pengabdian masyarakat yang dilakukan pada bulan November tahun 2021 di Wilayah Daerah Pasar Kranggan di Kecamatan Jati Sampurna dilakukan dengan cara mendatangi langsung para pelaku pengusaha UMKM (Mitra) Pedagang beras dan pedagang kelontong lainnya dengan melakukan dukungan, sosialisasi terkait dengan penggunaan aplikasi catatan keuangan, dan catatan pembukuan keuangan dan akuntansi sehari hari adalah sebagai berikut:

1. Memberikan penyuluhan dan sosialisasi mengenai penggunaan aplikasi catatan keuangan untuk mencatat trasaksi sehari hari dalam meningkatkan penghasilan dan pendapatan di masa pandemic Covid 19 khususnya sekitar daerah Pasar Kanggan KEcamatan Jati Sampurna Kota Bekasi Jawa Barat

2. Dukungan penuh kepada para pelaku usaha bidang perdagangan, industry kreatif. Untuk sektor perdagangan khususnya untuk pemenuhan kebutuhan Sembilan bahan Pokok (SEMBAKO) masyarakat di Masa Pandemi Covid 19.

3. Melakukan sosialisasi individu dengan mendatangi masing masing pelaku usaha UMKM pedagang Sembago terkait pencatatan transaksi keuangan harian dengan berbasis digital sarana aplikasi "Catatan Keuangan" khususnya para pedagang sembako, pedagang sayur dan buah menggunakan fasilitas Handphone atau Ipad dalam melakukan transaksi penerimaan dan pengelauran uang pada usaha UMKM tersebut.

4. Melakukan sosialisasi Kesehatan pentingnya menguatkan dan disiplin mengikuti protocol Kesehatan bagi para pelaku usaha bidang agrobisnis pertanian dalam melakukan kegiagtan bisnis usahanya supaya lebih produktif dan berhasilguna dalam menjang perekonomian nasional dan meningkatkan pertumbuhan ekonomi di Indonesia

\section{Hasil penelitian dan Pengabdian Kepada Mayarakat sesuai konten dan informan}

Pengabdian kepada masyarakat melalui sosialisasi penggunaan aplikasi catatan keuangan untuk mencatat transaksi harian UMKM kepada pedagang Sembako dan industri kerajinan dan Agrobisnis di Pasar Kranggan.

Diwakili oleh 10 informan perwakilan dari Pengusaha UMKM Kelompok Pedagang Kelontong penyedia bahan kebutuhan pokok masyarakat yang bergerak di sektor perdagangan terdiri dari pedagang beras dan pedagang sembilan kebutuhan pokok (SEMBAKO)

Tanggapan dari informan dalah sangat senang dan respon sekali melalui adanya sosialisasi penggunaan catatan keuangan karena mempemudah pencatatan transaksi keuangan sehari hari untuk mengetahi keuntungan dan sisa uang setiap harinya. Sebanyak 10 orang merasa puas dan senang bertransaksi dengan aplikasi catatan keuangan atau dengan tingkat kepuasan $100 \%$. 


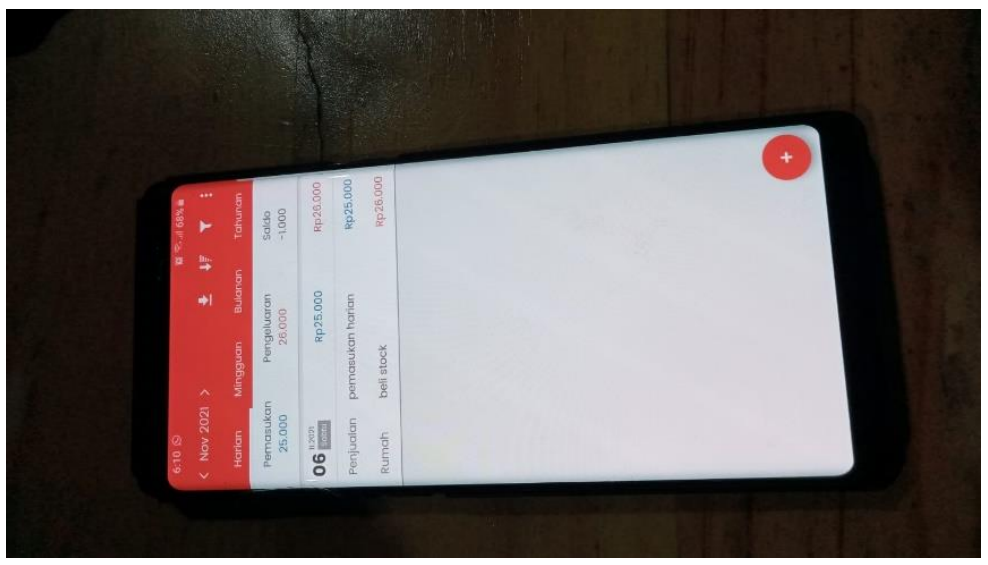

Gambar 2 Contoh Aplikasi Penggunaan Catatan Keuangan lewat media (Device) Hand Phone Seluler yang bisa di dowl load lewat PlayStore.

Pengabdian kepada masyarakat berupa memberikan cara penggunaan aplikasi catatan keuangan kepada/ bagi pelaku usaha UMKM khususnya para pelaku usaha Agrobisnis pertanian untuk terus meningkatkan produksinya secara integrasi dan jaringan dan penggunaan teknologi digital dan bidang sektor Agro bisnis pertanian dan bidang sektor perdagangan khususnya di daerah Pasar Kranggan.

Diwakili oleh 9 Informan dari para pedagang bisnis buah buahan agro bisnis pertanian dan sayur mayur di Pasar Kranggan.

Tanggapan dari tukang buah dan tukang sayur berpendapat bahwa mereka merasa lebih suka dengan cara konvensional dibandingkan dengan menggunakan aplikasi catatan keuangan.Terbuktu dari 9 orang informan, sebanyak 3 orang saja yang menyukai bertransaksi dengan menggunakan aplikasi catatan keuangan untuk mencatat aktifitas penjualannya setiap hari sedangkan 6 orang lainnya lebih menyukai dengan catatan manual.Artinya hanya sebanyak 33,33\% yang dapat menggunakan aplikasi catatan keuangan untuk mencatat aktifitas penjualnnya sehari hari dan sebanyak 66,67 \% lebih menyukai mencatat secara manual atau konvensional.

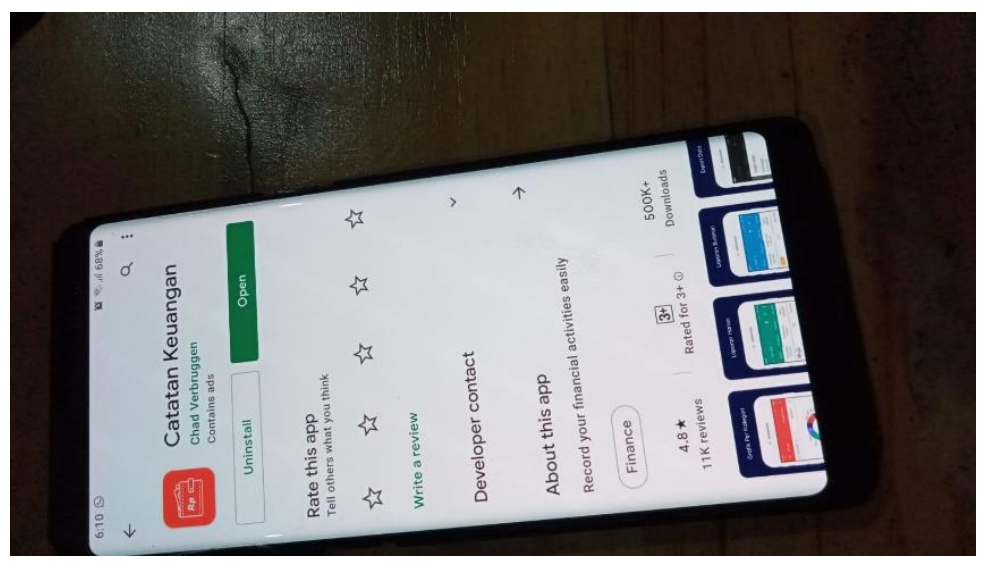

Gambar 3. Memberikan penjelasan mengenai aplikasi catatan keuangan kepada pelaku UMKM Tukang sayur dan tukang buah lewat Hand Phone 
Pengabdian kepada Masyarakat melalui dukungan serta memberikan masukan untuk meningkatkan hasil usahanya dengan digitalisasi dengan menggunakan aplikasi digital dari catatan keuangan lewat HandPhone atau Ipad di wilayah Kecamatan Jati Sampurna secara daring dan secara langsung ke lapangan seperti mendatangani pelaku UMKM di Pasar Kranggan.

Diwakili oleh 3 orang Informan Pengusaha UMKM (Mitra) yang bergerak dalam bidang hasil produk pertanian olahan, makanan dan minuman siap saji.

Tanggapan pengusaha UMKM (Mitra UMKM) yang bergerak di bidang makanan dan minuman siap saji rata rata para pedagang asongan, kelontongan, kedai makanan dan minuman di pinggir jalan atau toko kelontong. Mitra berpendapat sangat setuju dan menyukai catatan transaksi penjualan mereka lewat sarana aplikasi catatan keuangan. Umumnya mereka melakukan penjualan secara online sehingga lebih memudahkan mereka dalam mencatat transaksi keuangannya sehari ahri secara online juga. Artinya sebesar $100 \%$ puas atas penggunaan media aplikasi catatan keuangan.

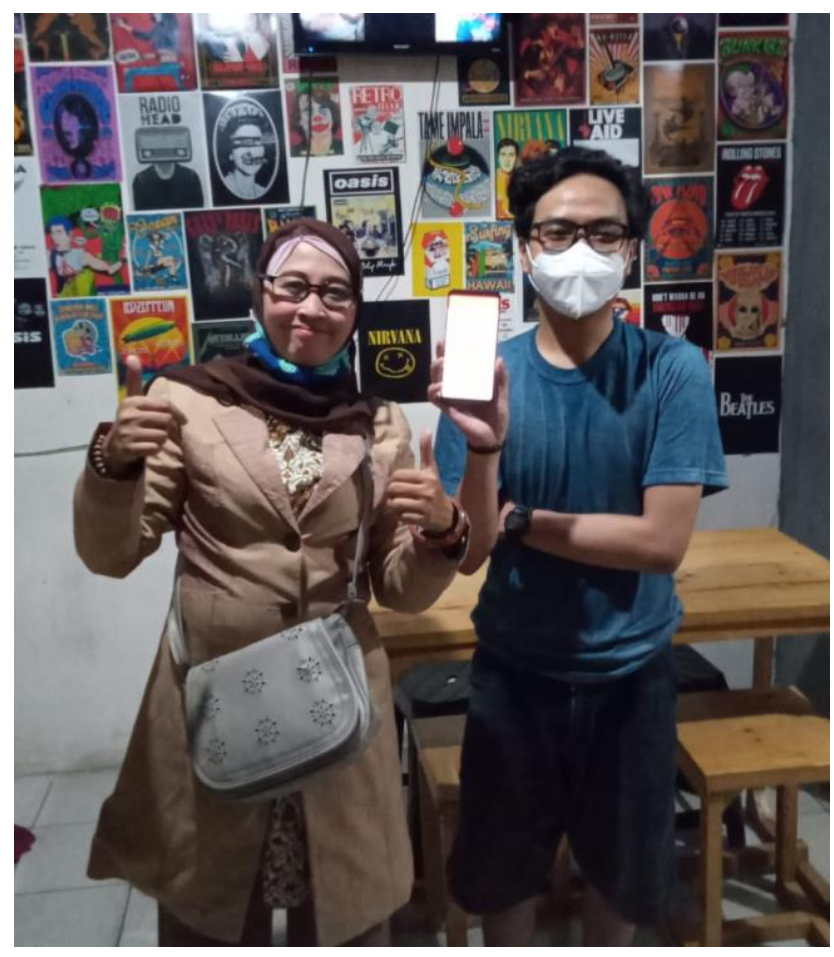

Gambar 4. Sosialisasi penggunaan aplikasi catatan keuangan untuk pedagang UMKM kepada pedagang makanan dan minuman siap saji di daerah Pasar Kranggan

Pengabdian Kepada Masyarakat mengenai pentingnya pencatatan trasaksi harian melalui aplikasi digitalisasi untuk mempermudah monitoring keuangan khususnya uang masuk dan uang keluar (penerimaan dan pengeluaran) atas aktifitas kegiatan sehari harinya untuk meningkatkan kinerja usaha UMKM di Pasar Kanggan. 
Diwakili oleh 3 orang Pedagang Online yaitu penjual makanan dan minuman siap saji (FAST FOOD) pada Hotel Avenze.Mereka umumnya melayani jualan online yang rutinitas transaksi catatan keuangannya dilakukan melalui cash register, catatan manual dan bersifat konvensional.

Tanggapan yang diperoleh, dengan adanya sosialisasi aplikasi keuangan ini mereka sangat antusias dan langsung berpraktik menggunakan aplikasi catatan keuangan untuk mencatat transaksinya sehari hari atas kegiatan penjualan online tersebut. Sebanyak 3 orang pedagang minuman dan makanan siap saji tersebut merasa puas dan mengerti untuk melakukan pencatatan transaksi keuangannya secara digital menggunakan aplikasi catatan keuangan. Artinya 100\% dari mereka merasa antusias dan puas dan paham untuk menggunakan aplikasi catatan keuangan tersebut.

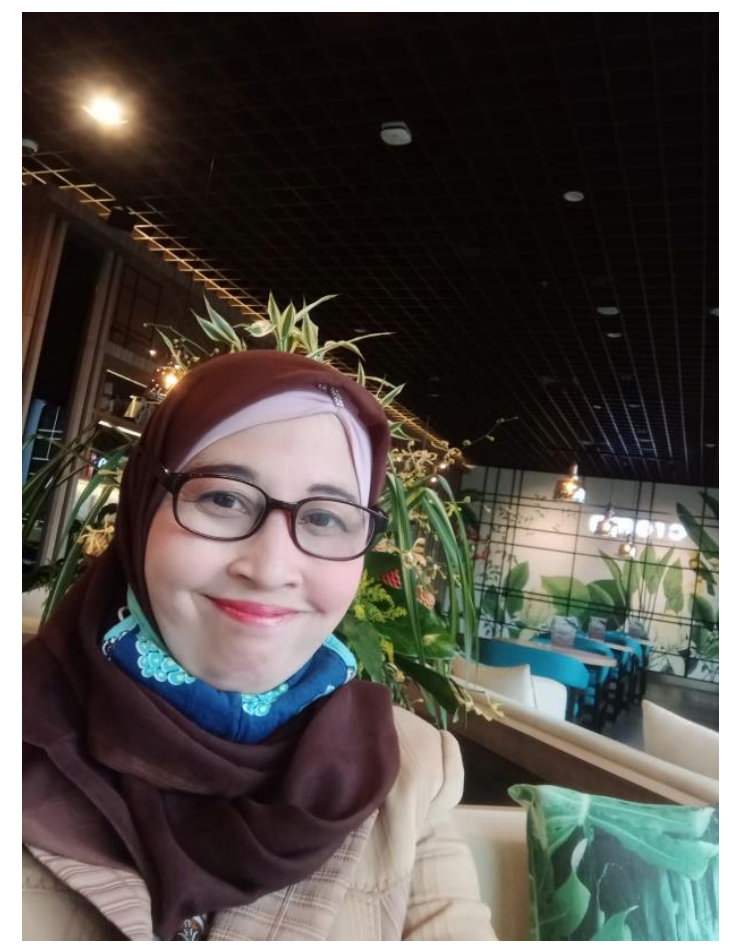

Gambar 5 Peneliti di restaurant Hotel Avenzel setelah melakukan wawancara penggunaan aplikasi catatan keuangan pada Fast Food Restauran Minuman dan Makanan Siap Saji.

\section{Simpulan Dan Rekomendasi}

Berdasarkan penjelasan diatas, adapun simpulan hasil Pengabdian Kepada Masyarakat dan penelitian tersebut berdasarkan hasil wawancara jarak dekat dan jarak jauh dari Pelaku usaha UMKM adalah:

1. Para pelaku Pengusaha UMKM khususnya para pedagang sembako, industri kreatif dan agro bisnis sangat antusis dan sangat puas mengharapkan perlu adanya sosialisasi lanjutan khusus untuk peningkatan laba usaha mereka dan penghasilan yang dapat meningkatkan produktifitas dan usaha UMKM tersebut secara berkesinambungan. 
2. Perlunya perhatian khusus instansi terkait bidang sektor bisnis perdagangan sembako terkait harga sembako yang agak mahal yang sering dikeluhkan oleh masyarakat setempat sehingga banyak pedagang mengeluh terkait omzet yang diterima. Hal ini sangat diperlukan dalam rangka mendukung ekonomi kerakyatan dan dalam hal memenuhi kebutuhan sembako masyarakat setempat seperti Kementerian Keuangan,Kementerian Pertanian, Kementerian Perekonomian, Kecamatan Jati Sampurna untuk saling koordinasi secara berkesinambungan dan berkelanjutan Program Peningkatan mutu dan kualitas perdagangan Sembako di daerah Pasar Kranggan melalui Program Subsidi Silang Antara Pemerintah Pusat dan Pemerintah Daerah melalui relokasi anggaran berkala bagi pelaku pengusaha pedagangan Sembago,industry kreatif dan agro bisnis khususnya yang terkena dampak Covid 19 melalui jaringan subsidi silang yang dapat dipertanggungjawabkan sesuai persyaratan tertentu untuk meningkatkan produktifitas kinerja sektor perdagangan dan industri BUMD secara langsung.

Rekomendasi dari kegiatan pengabdian kepada masyarakat adalah:

1. Kegiatan Pengabdian Kepada Masyarakat ini sangat mengharapkan adanya kajian khusus yang lebih mendalam dan evaluasi terkait adanya program sosialisasi secara berkesinambungan melalui literasi keuangan yang didukung oleh Pemerintah daerah setempat dan pihak lainnya yang terkait pemberdayaan dan peningkatakn pelayanan pelaku pengusaha UMKM khususnya para pedagang Sembako di Wilayah Pasar Kranggan Kecamatan Jati Sampurna dan di Indonesia khususnya sebagai sarana evaluasi mutu produktifitas kinerja UMKM dalam hal pencatatan keuangan transaksi harian pelaku terkait untuk peningkatan produktifitas kinerjanya dan menaikkan pendapatan dan penghasilannya bertujuan untuk peningkatan profitabilitas kinerja usaha UMKM dan masyarakat Indonesia dan peningkatan pertumbuhan ekonomi nasional di Indonesia.

2. Perlunya program sosialisasi literasi keuangan secara digital ini dalam rangka peningkatan penghasilan dan produktifitas kinerja UMKM di Wilayah Pasar Kranggan Kecamatan Jati Sampurna.

\section{Daftar Pustaka}

(APJII) 2017. Survei Asosiasi Penyelenggara Jasa Internet Indonesia. Dapat Akses melalui www.apjii.or.id

Amalia.2020. https://www.jurnal.id/id/blog/2018-memahami tentang bisnis model kanvas

Arikunto, Suharsimi .2010. Prosedur penelitian suatu pendekatan praktek, Penerbit Rineka Cipta. Jakarta

Dani Sugiri.2020. Menyelamatkan usaha mikro, kecil dan menengah dari dampak Covid 19, Focus Bisnis: Media Pengkajian manajemen akuntansi, Politeknik Keuangan STAN 
Dwiarta IMB, Chiria C.2017. Goodle Bisnis, SIM dan SIA guna menentukan HPP sebagai Sarana Meningkatkan pendapatan masyarakat. Penamas Adi Buana $\mathrm{I}(\mathrm{I}): 27-38$

Idah, Y.M. \& Pinilih, M. 2020. Strategi Pengembangan Digitalisasi UMKM. Prosiding Seminar nasional Dan Call for Papers "Pengembangan Sumber Daya Pedesaan Dan kearifan local berkelanjutan IX" 9 (1), 195-204.

Kementerian Koordinator Bidang Perekonomian Republik Indonesia. 2020. Siaran Pers H.M.4.6/175/SET.M.EKON.2.3/11/2020.Jakarta.Tanggal 18 November 2020

Pemerintah Repubik Indonesia. 2020. Peraturan Pemerintah Nomor 21 Tahun 2020 Tentang Pembatasan Sosial Berskala Besar

Sekaran. 2010. Edisi 5. Research method for Business A skill building approach. John Willey@Son New York City, USA.

Soetjiptono. 2020. Ketahanan UMKM Jawa Timur Melintasi Pandemi Covid 19.

Sugiyono. 2013. Metode penelitian kuantitatif, kualitatif dan R dan B Cetakan 19. Penerbit Alfabeth CV Bandung

Website: www.ekon.go.id.

Wuryandari. 2020. Dampak Pandemi Covid 19 terhadap Pertumbuhan Ekonomi Indonesia 2020 dan solusinya. Info singkat bidang Ekonomi dan Kebijakan Publik Pusat Penelitian Badan Keahlian DPT.RI.12.(15).19-24 